\title{
The Relationship between Social Exchange Variables and In-Role Performance, Organizational Citizenship Behavior, and Commitment: Evidence from Israeli Community Centers
}

\author{
Aaron Cohen ${ }^{1} \&$ Liat Blecher ${ }^{1}$ \\ ${ }^{1}$ School of Political Science Division of Public Administration, University of Haifa, Haifa, 31905, Israel \\ Correspondence: Aaron Cohen, School of Political Science, Division of Public Administration, University of \\ Haifa, Haifa, 31905, Israel.
}

Received: January 20, 2022

Accepted: February 24, 2022

Online Published: February 25, 2022

doi:10.5539/ijps.v14n1p74

URL: https://doi.org/10.5539/ijps.v14n1p74

\begin{abstract}
Community centers provide invaluable services for local communities worldwide. This study examines the relationships between social exchange variables (affection toward supervisors, job satisfaction, distributive justice, and psychological contract violation) and in-role performance, organizational citizenship behavior (OCB), and commitment forms (community center, job, and the local community). The target population consisted of employees from 24 community centers working for national nonprofit organizations in Israel. A total of 176 questionnaires were distributed, and 129 employees returned usable questionnaires (a response rate of 73\%). Supervisors provided information on in-role performance and OCB. The findings show that affection toward supervisors has a strong positive relationship with the three investigated commitment forms and altruistic OCB. Further, psychological contract violation has a negative relationship with in-role performance and OCB. Therefore, we conclude that the process of social exchange represents an important mechanism for increasing in-role performance, OCB, and commitment.
\end{abstract}

Keywords: community centers, OCB, social exchange, psychological contract violation, affection toward supervisors

\section{Introduction}

Community centers are leading social organizations that aim to develop a nationwide network of workable local communities that contribute to a strong society (Stetsky \& Kamagina, 2021). Community centers in Israel are relatively new organizations as they were founded in the late 1960s (Hasenfeld \& Schmidt, 1989). Their goal is to develop and manage progressive complementary educational frameworks and lifelong learning, and to comprehensively aid community members with special needs and for a wide range of ages. To date, there are about 700 operative community centers in Israel that assist millions of citizens in more than 200 local municipalities (Israeli Associations of Community Centers, 2020). Israeli community centers also implement extra-curricular activities in Israeli high schools with the aim of providing recreation and relaxing tension, as well as enabling students to express themselves in areas that interest them (Cohen \& Schmidt, 1997).

Each community center in Israel is assimilated as a public organization with a public board that represents a local municipality, citizen groups, and social service agencies. The centers are connected with the Israeli Association of Community Centers, which selects and hires the center director. However, the budget and operation of each center are regulated by local authorities. Therefore, contrary to other public social services whose policies, programs, and budgets are controlled centrally (Hasenfeld \& Schmidt, 1989), the community centers are operated by members of the local community and their activities reflect the desires of the locals. Most centers depend on volunteers from the community and enable them to participate in voluntary and mutual aid activities intended to improve the total welfare of the community (Hasenfeld \& Schmidt, 1989).

Earlier studies on Israeli community centers were descriptive and qualitative in nature (Perlman, 1981; Hasenfeld \& Schmidt, 1989), whereas recent studies have performed quantitative analysis to investigate the attitudes and behaviors of members of Israeli community centers. Cohen and Freund (2005) examined turnover intentions in three time lags and found that commitment forms (affective organizational commitment, continuance organizational commitment, occupational commitment, and job involvement) were associated with turnover 
intentions even when turnover intentions were measured earlier or at the same time when commitment forms were controlled for. Using the same sample, Freund (2005) found a significant relationship between affective and continuance organizational commitment and job satisfaction. Additionally, Freund pointed out that career commitment and job satisfaction were significantly related to withdrawal intentions and thinking of quitting from the community center.

Using a sample of Arab and Jewish participants in 14 community centers in Israel, Galin and Avraham (2009) examined aggressiveness in the workplace, finding that ethnic groups predict aggressive behavior, and gender predicts aggression within each ethnic group. Using a sample of 290 employees and 15 managers in Israeli community centers, Carmeli et al. (2009) found that bonding special capital mediated the relationship between leader relational behavior and employee vigor. Vigor also mediated the relationship between social capital and employee job performance. Shmidt (2002) examined executive directors and their immediate subordinates, finding that decentralized management and delegation of authority are important for achieving the goals of community centers.

Although the above studies examined important aspects of the work environment of community centers, there is a need for more studies. The goal of this research is to examine the correlates of organizational citizenship behavior $(\mathrm{OCB}$,$) and attitudes (commitment forms) for community centers' employees in Israel. Using the social exchange$ theory, this study argues that variables that represent social exchange (i.e., affection toward supervisors, job satisfaction, distributive justice, and psychological contract violation) are positively associated with the three commitment forms (commitment center, job, and local community) as well as in-role performance and OCB as reported by the manager of each community center.

\section{Literature Review and Hypotheses}

\subsection{Dependent Variables}

\subsubsection{Organizational Citizenship Behavior (OCB)}

OCB has been extensively studied in the literature on management and organizational behavior (Ehrhart \& Naumann, 2004; Ocampo et al., 2018). It refers to behaviors that contribute to an organization but are not part of the employees' job duties and are not formally acknowledged by the organization. Such behaviors are also described as spontaneous behaviors and are not compensated for by the organization. OCB has two dimensions: OCB toward organizations (OCB-O), which refers to behaviors directed toward the organization in general and OCB toward individuals (OCB-I), which refers to assisting specific individuals within the organization, including co-workers and supervisors (Henderson et al., 2020; Organ, 2006). The determinants of OCB were examined within the theoretical framework of social exchange, with most studies focusing on the situational attitudes of subordinates, such as their relationships with their supervisors, the supervisors' leadership style, the specific work context, and so on (Carpenter et al., 2014; Khaola \& Rambe, 2020; Konovsky \& Pugh, 1994; Podsakoff et al., 2000; LePine et al., 2002). Nevertheless, few studies have examined OCB in the context of community centers. This study fills this literature gap by examining how social exchange variables are associated with OCB-O, OCB-I. In addition, the study also examined in-role performance following Williams and Anderson's (1991) recommendation to use in-role performance as control variable that verify the accuracy of the measurement of OCB.

\subsubsection{Commitment}

Commitment in the workplace is one of the most researched concepts in the literature on management and organizational behavior (van Rossenberg et al., 2018; Cohen \& Veled-Hecht, 2010). Although there are many definitions of commitment, according to the mainstream approach, it reflects feelings such as loyalty, identification, and attachment to the object of commitment (Morrow, 1983, 1993). Further, according to Rotondi (1975), there is a need to separate between targets of commitment, such as task groups, occupational activities, and reference groups. One of the recently leading approaches to commitment is to view it as a multidimensional concept (Cohen, 2003; Klein, Solinger, \& Duflot, 2022), with many studies adopting this approach (e.g., Morrow, 1982, 1993; Reichers, 1985, 1986; Becker, 1992; Cohen, 2000, 2003; Klein et al., 2014). Such conceptual and empirical studies have formed what can be termed as the multiple commitment approach. However, very few studies have examined this approach in the context of community centers. Therefore, to fill this literature gap, this study examines how social exchange variables are associated with three commitment forms: commitment to the community center, the job, and the local community. 


\section{Research Hypotheses}

\subsection{Affection toward Supervisors}

Liden and Maslyn (1998) introduced a multidimensional leader-member exchange (LMX) scale that includes one dimension to measure the subordinates' affection toward their supervisors. This affective component of leader-subordinate relationships plays a critical role in the LMX scale (Liden et al., 1993). According to the social exchange theory, employees perform more efficiently when they have a good relationship with their supervisors (Liden et al., 1997) due to the "norms of reciprocity." That is, when employees receive positive treatment, they are inclined to develop emotional ties with their organization and supervisors (Miao et al., 2020). The possible result of such a process may be higher levels of motivation among employees, leading to extra-role behavior (Chen \& Kanfer, 2006). Some studies have validated this argument by finding a positive relationship between the LMX scale and innovative behaviors (Hammond et al., 2011; Volmer et al., 2012).

When the supervisor fulfills the employee's work values, the employee will develop positive feelings about the supervisor, resulting in a high-quality relationship between the supervisor and the employee. This leads to high job satisfaction of the employee, thus making her or him more willing to exert extra effort by increasing job performance and engaging in OCB (Marstand et al., 2017). Carmeli et al. (2009) found an indirect relationship between leader relational behavior and job performance among employees in Israeli community centers. Further, they showed that when employees experience quality workplace relationships, such as care, closeness, and being confident in getting assistance from colleagues, they report high drive and energy, thus increasing their job performance.

Moreover, the affective connection that employees develop with their organization may be based on the affective bond they develop with their immediate supervisor. Since a supervisor has a direct influence on the work experience of her or his subordinates, it is reasonable to expect a positive relationship between affection toward supervisors and work outcomes (Gerstner \& Day, 1997). In other words, employees' affective attachment to the supervisor results from the reciprocal exchange of emotional support, which enhances the employees' commitment, in-role performance, and $\mathrm{OCB}$, as the supervisor is the key organizational representative of the corporation's leadership (Hackett \& Lapierre, 2004).

Therefore, we postulate the following hypothesis:

Hypothesis 1: Affection toward the supervisor is positively related to the employee's commitment, in-role performance, and $O C B$.

\subsection{Job Satisfaction}

Job satisfaction is considered one of the important correlates of OCB (Organ, 1990; Organ \& Konovsky, 1989; Foote \& Tang, 2008; Sesen \& Basim, 2012). In particular, it is associated with certain types of OCB (Schnake, 1991). Two reasons may explain the relationship between job satisfaction and OCB. First, this association is based on an exchange relationship, in which people seek to reciprocate those who benefit from them. When the employee gain satisfaction due to efforts of the employer, and these efforts are interpreted by the employee as reliable and non-manipulative in intent, the employee will reciprocate to those efforts by high levels of in-role performance and OCB (Bateman \& Organ, 1983). According to Organ, the employees' levels of in-role performance and OCB depend on their perceptions of fair treatment from their employer. Second, mood states affect the probability of OCB. Employees with positive mood states, as a result of prior success on a difficult task or based on past enjoyable experiences, are more likely to behave altruistically (Smith et al., 1983; Torlak et al., 2021). Conversely, employees with negative mood states are less likely to demonstrate prosocial behavior. Smith et al. (1983) suggested that as long as job satisfaction represents the characteristics of a positive mood state, it could explain a portion of OCB. Further, Bateman and Organ (1983) reported a strong relationship between job satisfaction and OCB.

The explanation of the relationship between job satisfaction and commitment also relies on the social exchange theory (Martin \& Bennett, 1996; Saridakis et al., 2020). Job satisfactionrepresents an immediate affective response; therefore, it develops soon after organizational entry, whereas organizational commitment represents an affective response to the treatment of the organization (Vandenberg \& Lance, 1992; Martin \& Bennet, 1996; Cohen, 2016). Meanwhile, organizational commitment, because of its macro perspective, develops slower than job satisfaction, and only after the employee develops an understanding of not only her or his job but also of other aspects of the organization. This understanding will determine the employee's attitude toward the organization, particularly organizational commitment and job commitment. Nevertheless, no relationship is expected between 
job satisfaction and commitment to the community, as they share only non-work experiences. Hence, we put forward the following hypothesis:

Hypothesis 2: High job satisfaction is positively related to the employee's in-role performance, OCB, and commitment to job and organizational commitment, but not to his or her commitment to the local community.

\subsection{Distributive Justice}

In line with the social exchange theory, individuals perceive their relationship with the employer as an acceptable commodity for exchange. The quality of this relationship is based on the principle of reciprocity (Coyle, Shapiro, \& Kessler, 2003). Distributive justice is based on equity theory, which contends that perceptions of unfair distribution of work rewards relative to work input create tension within the individual that she or he will attempt to resolve (Aggarwal, Nobi, \& Rastogi, 2020; Moorman, 1991; Organ, 1988, 1990; 1995). When employees perceive that they receive inducement that is commensurate with their knowledge, skills, and abilities, they are more likely to think that outcomes such as pay, terms of work, and benefits are fair and just (Ang et al., 2003; Greenberg, 1990; Cohen, 2016). These employees will reciprocate with higher levels of commitment to the organization and the job, as well as higher levels of in-role performance and OCB (Aggarwal et al., 2020; Niehoff \& Moorman, 1993; Organ, 1990). According to Organ (1988), OCB can be the result of perceptions of inequity or equity. High inequity leads to lower OCB, whereas low inequity leads to higher levels of OCB. Thus, we propose the next hypothesis:

Hypothesis 3: High levels of distributive justice are positively related to in-role performance, $O C B$, and job and organizational commitment, but not to community commitment.

\subsection{Psychological Contract Violation}

A psychological contract violation occurs when the organization fails to fulfill one or more of its promises (not written or contractual) in the employment relationship (Tufan \& Wendt, 2020). That is, a psychological contract violation can occur when there is a discrepancy between what is perceived to have been promised and what actually has been performed (Coyle-Shapiro, 2002; Coyle-Shapiro et al., 2019). Employees who think that the organization has breached the terms of the psychological contract are not expected to participate in spontaneous behavior that contributes to the organization, such as OCB (Ramamoorthy et al., 2005). In any case, contract violation will decrease employees' motivation to fulfill in-role performance and to perform OCB (Zhong, Wayne, \& Michel, 2021; Zhao et al., 2007).

The same logic is also applicable to commitment. When employees think that the employer breached the psychological contract, they will respond by lowering their commitment. Additionally, psychological contract violation is expected to reduce identification and trust in the organization, which causes employees to put their interest before that of the employer (Cassar \& Briner, 2011). Further, when employees believe that their organization has not fulfilled its obligations and promises, they are likely to feel betrayed, angry, and undervalued, and will reciprocate with low emotional attachment and commitment to the organization and the job (Coyle-Shapiro et al., 2019; Quratulainet et al., 2018). However, there is no expectation that a breach of the psychological contract is related to commitment to the local community. Thus, we postulate the following hypothesis:

Hypothesis 4: Perception of psychological contract violation is negatively related to OCB, in-role performance, and commitment to the organization and the job, but not to commitment to the community.

\subsection{Control Variables}

Three control variables were examined in this research: gender, tenure in the community center, and marital status. First, as for gender, there is evidence that despite societal changes, females still perform more household duties than males (Karsten, 1994; Ross, 1987). Therefore, it can be expected that women will have more household responsibilities leading to role conflict and lower levels of work performance and commitment (Ajlouni, Kaur, \& Alomari, 2021). Second, marital status is an important correlate of performance because employees who are not married do not have family responsibilities and can have more free time and energy to put more effort into in-role performance and OCB, as well as being more committed to work (Bharthy \& Sethi, 2020). Russell and Rush (1987) found an association between marital status and dimensions of performance. Third, tenure is considered a determinant of commitment in the workplace (Cohen \& Lowenberg, 1990; Cohen, 1993; Timalsina, Rai, \& Chhantyal, 2018), because it increases the investment of employees in the organization and their commitment to it. Thereby, employees with more tenure will have a stronger attachment to the organization and job and will invest more in OCB and in-role performance (Mohammad et al., 2010). 


\section{Methods}

\subsection{Research Design}

The population of this study was community centers' employees in Israel. Data were collected from 24 community centers. From the 176 questionnaires that were distributed, 129 completed questionnaires (a response rate of $73 \%$ ) were received. The employee questionnaires included the three commitment forms, affection toward supervisors, job satisfaction, distributive justice, and psychological contract violation. A few months after the questionnaires were collected from the employees, supervisors filled out questionnaires about in-role performance and OCB. The questionnaires were translated from English by native speakers of Hebrew and English, using the common process of translation and back-translation.

In total, the average age of participants was 41 , and $61 \%$ were women. They had average tenure of 7.5 and 6.9 years in the community center and occupation, respectively. Furthermore, $79 \%$ of participants were married. Regarding education, $47 \%$ received non-academic education while $53 \%$ had academic education, including master's degrees and higher education.

\subsection{Data Analysis}

The measurement mode of the study scales was tested by applying confirmatory factor analysis (CFA), using a structural equation-modeling program. The study used the procedure developed by Brooke et al. (1988) and Mathieu and Farr (1991). The data were analyzed using the SPSSX hierarchical linear mode because the sample included employees from 24 community centers (Bryk \& Raudenbush, 1992, pp. 84-86).

\subsection{Scales}

OCB and in-role performance were measured using Williams and Anderson's (1991) scale. This scale consists of three dimensions with seven items each: in-role performance (sample item: "Adequately complete assigned duties"), organizational OCB (sample item: "Conserves and protects organizational property"), and personal OCB (Sample item: "Helps others who have been absent"). Response options ranged from 1 (never) to 5 (always). This variable was reported by the supervisors.

Commitment to the community center, job, and community were measured using the four-item scale developed by Klein et al. (2014). The items were adjusted to the relevant commitment foci (Sample items: "How committed are you to [target]?"; "To what extent do you care about [target]?"; "How dedicated are you to [target]?").

"Affection toward supervisors" was measured using a three-item scale based on Sears and Hackett's (2011) scale. Respondents were asked to indicate the extent to which their center managers (a) encouraged collaboration, (b) cultivated a trustful work environment, and (c) encouraged open communication.

Job satisfaction was measured using the four-item scale developed by Hoppe et al. (2014). Response options ranged from 1 to 7 , with higher numbers indicating higher job satisfaction (sample items: "Would you take the same job if you had the choice to start over again," "Would you take the same job if you were free to go into any job you wanted?").

Psychological contract violation was measured using the five-item scale developed by Robinson and Morrison (2000) (Sample items: "Almost all promises made by my employer during recruitment have been kept so far (reversed)"; My employer has broken many of its promises to me although I've upheld my side of the deal").

Distributive justice was measured using Niehoff and Moorman's (1993) five-item scale (Sample items: "My work schedule is fair"; "I think that my level of pay is fair"; "I consider my workload to be quite fair").

For all questionnaires (except for the OCB and in-role performance scale, which ranged from 1 to 5), responses were given on a scale from 1 (strongly disagree) to 7 (strongly agree).

\subsection{Control Variables}

Sex $(0=$ male; $1=$ female $)$ and marital status $(0=$ not married; $1=$ married $)$ were measured as dichotomous variables, while community center tenure was measured as a ratio variable.

\section{Results}

Table 1 presents the descriptive statistics of the research variables and their intercorrelations. The results showed acceptable reliability of the variables. None of the correlations (except for the relationship between in-role performance and organizational $\mathrm{OCB}$ ) exceeded 0.65 , thus reducing the possibility of multicollinearity. 
Table 1. Descriptive statistics, reliabilities (in parentheses), and inter-correlations among research variables

\begin{tabular}{|c|c|c|c|c|c|c|c|c|c|c|c|c|c|c|c|}
\hline Variables & Mean & SD & 1 & 2 & 3 & 4 & 5 & 6 & 7 & 8 & 9 & 10 & 11 & 12 & 13 \\
\hline 1. Sex & .59 & .49 & & & & & & & & & & & & & \\
\hline 2. Marital status & .78 & .41 & -.03 & & & & & & & & & & & & \\
\hline $\begin{array}{l}\text { 3. Tenure in } \\
\text { Organization }\end{array}$ & 7.65 & 7.00 & -.02 & $.18^{*}$ & & & & & & & & & & & \\
\hline $\begin{array}{l}\text { 4. Affection toward } \\
\text { supervisors }\end{array}$ & 6.15 & .78 & .02 & -.03 & -.09 & $(.84)$ & & & & & & & & & \\
\hline 5. Job satisfaction & 5.61 & .96 & .11 & -.12 & $-.34^{* * *}$ & $.49^{* * *}$ & $(.82)$ & & & & & & & & \\
\hline $\begin{array}{l}6 . \quad \text { Distributive } \\
\text { justice }\end{array}$ & 4.86 & 1.06 & -.09 & -.11 & $-.26^{* *}$ & $.31 * * *$ & $.45^{* * *}$ & $(.74)$ & & & & & & & \\
\hline $\begin{array}{l}\text { 7. Psychological } \\
\text { contract violation }\end{array}$ & 2.65 & 1.03 & -.05 & -.01 & $.29^{* * *}$ & $-.56^{* * *}$ & $-.58^{* * *}$ & $-.37^{* * *}$ & $(.75)$ & & & & & & \\
\hline $\begin{array}{l}\text { 8. Community } \\
\text { center commitment }\end{array}$ & 6.23 & .71 & .05 & -.03 & -.07 & $.60^{* * *}$ & $.39^{* * *}$ & .16 & $-.31^{* * *}$ & $(.89)$ & & & & & \\
\hline 9. Job commitment & 6.32 & .61 & .05 & -.03 & -.09 & $.60^{* * *}$ & $.54^{* * *}$ & .07 & $-.47^{* * *}$ & $.63^{* * *}$ & $(.80)$ & & & & \\
\hline $\begin{array}{l}\text { 10. Community } \\
\text { commitment }\end{array}$ & 6.11 & .68 & .10 & -.06 & -.13 & $.47^{* * *}$ & $.42^{* * *}$ & $.22^{*}$ & $-.25^{* *}$ & $.55^{* * *}$ & $.52^{* * *}$ & (.87) & & & \\
\hline $\begin{array}{l}11 . \quad \text { In-role } \\
\text { performance }\end{array}$ & 4.05 & .62 & -.12 & .06 & .01 & $.24^{* *}$ & -.02 & .05 & $-.28^{* *}$ & $.20^{*}$ & $.27^{*}$ & .11 & $(.82)$ & & \\
\hline 12. OCB altruistic & 3.73 & .67 & .06 & .12 & .14 & .15 & -.10 & -.09 & -.06 & .05 & .10 & .03 & $.32^{* * *}$ & $(.90)$ & \\
\hline $\begin{array}{ll}13 . & \mathrm{OCB} \\
\text { organization } & \end{array}$ & 3.82 & .58 & -.14 & $.19^{*}$ & .01 & $.23^{*}$ & -.04 & .04 & $-.31^{* * *}$ & .18 & $.22^{*}$ & .08 & $.81^{* * *}$ & $.24^{* *}$ & $(.72)$ \\
\hline
\end{tabular}

Note. $\mathrm{N}=129 . *=\mathrm{P} \leq .05 ; * *=\mathrm{P} \leq .01 ; * * *=\mathrm{P} \leq .001$

Gender: $0=$ male, $1=$ female; Marital status: $0=$ not married, $1=$ married.

OCB $=$ Organizational citizenship behavior

Table 2. CFA for research constructs

\begin{tabular}{lllllllll}
\hline Model & df & $\chi \mathbf{2}$ & $\boldsymbol{\chi 2} \mathbf{d d f}$ & CFI & NFI & IFI & TLI & RMSEA \\
\hline Commitment forms & & & & & & & & \\
One-factor solution & 27 & 204.60 & $7.58^{* * * * *}$ & .75 & .73 & .76 & .59 & .23 \\
Three-factor solution & 24 & 44.80 & $2.67^{* *}$ & .97 & .94 & .97 & .95 & .08 \\
$O C B$ & & & & & & & & \\
One-factor solution & 27 & 269.29 & $9.97^{* * *}$ & .60 & .58 & .60 & .32 & .26 \\
Three-factor solution & 24 & 67.76 & $2.82^{* * *}$ & .93 & .89 & .93 & .86 & .12 \\
\hline
\end{tabular}

Note. $N=129$.

OCB $=$ Organizational citizenship behavior

$*=P \leq .05 ; * *=P \leq .01 ; * * *=P \leq .001$

Additionally, we performed CFA on the multidimensional variables (see Table 2). First, for the commitment dimensions, we compared the fit of two models (three-factor and one-factor), with the results revealing better fit indices for the three-factor model. Similarly, we compared the fit of a three-factor model for OCB (altruistic $\mathrm{OCB}$, organizational $\mathrm{OCB}$, and in-role performance as a control variable for $\mathrm{OCB}$ ) to that of an alternative one-factor model. Again, the results for the three-factor model showed better fit indices. These results are consistent with the absence of common method variance.

Results of the hierarchical linear modelling (HLM) analysis (see Table 3) showed positive and significant effects of affection toward supervisors on altruistic OCB but not on organizational OCB and in-role performance, and on all three dimensions of commitment, thus partially supporting Hypothesis 1. 
Table 3. HLM Analyses (estimates) of the effect of demographic and social exchange variables on OCB and commitment forms (community centers, job, and community) $(\mathrm{N}=129)$

\begin{tabular}{|c|c|c|c|c|c|c|}
\hline \multirow[b]{2}{*}{$\begin{array}{l}\text { Dependent variables } \\
\text { Independent variables }\end{array}$} & \multicolumn{3}{|l|}{$\underline{\mathrm{OCB}}$} & \multicolumn{3}{|c|}{ Commitment forms } \\
\hline & $\underline{\text { In-role }}$ & Organization & $\underline{\text { Altruistic }}$ & $\frac{\text { Community }}{\text { center }}$ & $\underline{\text { Job }}$ & community \\
\hline Intercept & $5.10 * * *$ & $5.40 * * *$ & $2.64 *$ & $2.20 * *$ & $3.88^{* * *}$ & $2.23 * *$ \\
\hline \multicolumn{7}{|l|}{ Demographics } \\
\hline 1. Sex & -.05 & -.07 & .09 & .06 & .02 & .08 \\
\hline 2. Marital status & .01 & .21 & .08 & .06 & .03 & .12 \\
\hline $\begin{array}{l}\text { 3. Tenure in } \\
\text { organization }\end{array}$ & .00 & -.00 & .01 & -.00 & .00 & -.01 \\
\hline $\begin{array}{l}\text { Social exchange } \\
\text { variables }\end{array}$ & & & & & & \\
\hline $\begin{array}{l}\text { 4. Affection toward } \\
\text { supervisors }\end{array}$ & .10 & -.01 & $.26^{*}$ & $.54 * * *$ & $.29 * * *$ & $.37 * * *$ \\
\hline 5. Job satisfaction & $-.21 *$ & $-.21 * *$ & -.07 & .12 & $.28 * * *$ & $.21 *$ \\
\hline 6. Distributive justice & -.02 & -.00 & -.05 & -.04 & $-.17 * * *$ & .01 \\
\hline $\begin{array}{l}\text { 7. Psychological } \\
\text { contract violation }\end{array}$ & $-.16^{*}$ & $-.18^{*}$ & -.01 & .07 & -.06 & .11 \\
\hline 2 log likelihood & 183.64 & 149.56 & 216.40 & 214.38 & 155.60 & 217.78 \\
\hline
\end{tabular}

Note. $\mathrm{N}=129 ; *=\mathrm{P} \leq .05 ; * *=\mathrm{P} \leq .01 ; * * *=\mathrm{P} \leq .001$

Sex: $0=$ male, $1=$ female; marital status: $0=$ not married, $1=$ married.

$\mathrm{OCB}=$ Organizational citizenship behavior.

Job satisfaction was found to be unexpectedly significantly negatively related to in-role performance and organizational OCB. As expected, job satisfaction was positively related to job commitment, and was not related to commitment to community. However, unexpectedly it was related to commitment to the community (see Table 3). Therefore, Hypothesis 2 was partially supported.

According to the results, justice was not related to OCB or in-role performance. It was only related negatively to job commitment. Thus, Hypothesis 3 was not supported by the data.

Psychological contract violation was found to be negatively and significantly related to in-role performance and organizational OCB (but not to altruistic OCB). However, it was not related to any of the commitment forms. Thus, Hypothesis 4 was partially supported.

As for the control variables, no significant relationships were found between any of the demographic variables and any of the OCB dimensions or commitment forms.

\section{Discussion}

This study examined the relationship between social exchange variables and the employees' commitment forms (self-reported) and OCB (reported by supervisors), within a context that has rarely been examined empirically. In general, the findings showed that in community centers, social exchange relationships represent a central process for enhancing in-role performance, $\mathrm{OCB}$, and commitment. In line with previous studies on leadership (Fuller et al., 1996; Judge \& Piccolo, 2004; Lowe et al., 1996), our findings showed strong, positive, and consistent relationships between affection toward supervisors and all three commitment forms and altruistic OCB. Therefore, affection toward supervisors provides an important social exchange mechanism for increasing OCB and commitment, which can operate through inspiration provided by a positive relationship with the leader. The findings also showed that in-role performance and organizational OCB are negatively related to psychological contract violation.

The two dimensions of performance (in-role performance and OCB-O) that were not related to affection toward supervisors were associated with psychological contract violation. Hence, this combination of the relationship of affection toward supervisors and psychological contract violation with commitment and OCB is worth noting 
because it provides an interesting insight into social exchange relationships. Affection toward supervisors suggests that when leaders are trusted and respected, they can persuade followers to sacrifice their own personal interests for the sake of the collective good (Yukl, 1989; Marstand et al., 2017). The employees come to identify with collective goals and problems (the organization, jobs in the community centers, or the general community), which are given significance by the leader, and which then become the foundation of a common social identity. This shared identity inspires employees to greater commitment and helping behavior (altruistic OCB), as they work together to overcome obstacles that impede their common long-term goals (Abd El Majid \& Cohen, 2015). Conversely, the findings show that behaviors that are less collective and value-oriented while focusing on more materialistic interests of the organization are affected more by the way the organization fulfills its promises to employees (psychological contract violation). Future studies should further examine this finding.

Job satisfaction was positively related to job commitment and the community commitment. The negative relationship between job satisfaction and in-role performance and OCB-O can be attributed to the specific work settings and organizational cultures of community centers. Following Yun et al. (2007), role ambiguity in community center employees' unique jobs might lead them to low job satisfaction. However, when role ambiguity is high, there is much room for employees to develop different interpretations of their job requirements. Thereby, there are few situational constraints on the employees, and they have a high degree of discretion regarding how they do their job, thus enabling them to integrate more job aspects into their roles and providing greater opportunities for them to engage in OCBs. Practically the main finding show that community centers should pay attention to the relationship between the supervisor and the workers in the Israeli community centers. It is important to select a supervisor that will develop trust and support relationship with the employees in the community centers.

Nevertheless, this study has some limitations. First, it was based on a snapshot-in-time study design. Such a design entails a single observation with no control group and limited control of the variables' effects. Second, only one occupation was examined, and one should be cautious about generalizing the results to other occupational groups. Third, since the study was performed in the Israeli context, its findings might be relevant only to this particular culture. Therefore, this study should be replicated in other settings and cultures before a conclusion on generalization can be drawn. Nevertheless, despite its limitations, the results clarify the motives, attitudes, and behavior of community center employees, an occupation rarely examined regarding commitment and extra-role behaviors. In particular, the findings verify the importance of social exchange relationships in determining the positive attitudes and behaviors of community center employees. The current literature would benefit from further research on the factors that affect the attitudes and behaviors of members of this important occupation.

\section{Conflict of Interest}

We have no known conflict of interest to disclose.

\section{References}

Abd El Majid, I., \& Cohen, A. (2015). The role of the principal's values and perceived leadership style in developing citizenship behaviors and in-role performance among Arab teachers in Israel. Leadership and Organization Development Journal, 36(3), 308-327. https://doi.org/10.1108/LODJ-06-2013-0077

Adams, J. S. (1965). Inequity in social exchange. In L. Berkowitz (Ed.), Advances in Experimental Social Psychology. New York: Academic Press. https://doi.org/10.1016/S0065-2601(08)60108-2

Aggarwal, A., Nobi, K., \& Rastogi, S. (2020). Linking structural empowerment and distributive justice to employee's behavioral and attitudinal consequences: Testing the mediating role of psychological empowerment. Journal of Public Affairs, e2418. https://doi.org/10.1002/pa.2418

Ajlouni, W. M. E., Kaur, G., \& Alomari, S. A. (2021). The Impact of Employees' Gender and Age on Organizational Citizenship Behavior Using a Fuzzy Approach. Social Science Computer Review, 39(6), 1237-1252. https://doi.org/10.1177/0894439320971234

Ang, S., Van Dyne, L., \& Begley, T. M. (2003). The employment relationships of foreign workers versus local employees: A field study of organizational justice, job satisfaction, performance, and OCB. Journal of Organizational Behavior, 24, 561-583. https://doi.org/10.1002/job.202

Bateman, T. S., \& Organ, D. W. (1983). Job satisfaction and the good soldier: The relationship between affect and employee "citizenship". Academy of Management Journal, 26(4), 587-595. https://doi.org/10.5465/255908 
Becker, T. E. (1992). Foci and bases of commitment: Are they distinctions worth making? Academy of Management Journal, 35, 232-244. https://doi.org/10.5465/256481

Bharthy, H., \& Sethi, U. J. (2020). Organisational Citizenship Behaviour: effect of gender, age and marital status on altruistic behaviour. Asia-Pacific Journal of Management Research and Innovation, 16(3), 188-195. https://doi.org/10.1177/2319510X21998827

Brooke, P. P., Russell, D. W., \& Price, J. L. (1988). Discriminant validation of measures of job satisfaction, job involvement and organizational commitment. Journal of Applied Psychology, 73, 139-145. https://doi.org/10.1037/0021-9010.73.2.139

Bryk, A., \& Raudenbush, S. (1992). Hierarchical Linear Models: Applications and Data Analysis Methods. Newbury Park, CA: Sage.

Carmeli, A., Ben-Hador, B., Waldman, D. A., \& Rupp, D. E. (2009). How leaders cultivate social capital and nurture employee vigor: Implications for job performance. Journal of Applied Psychology, 94(6), 1553-1561. https://doi.org/10.1037/a0016429

Carpenter, N. C., Berry, C. M., \& Houston, L. (2014). A meta-analytic comparison of self-reported and other-reported organizational citizenship behavior. Journal of Organizational Behavior, 35, 547-574. https://doi.org/10.1002/job.1909

Cassar, V., \& Briner, R. B. (2011). The relationship between psychological contract breach and organizational commitment: Exchange imbalance as a moderator of the mediating role of violation. Journal of Vocational Behavior, 78(2), 283-289. https://doi.org/10.1016/j.jvb.2010.09.007

Chen, G., \& Kanfer, R. (2006). Toward a systems theory of motivated behavior in work teams. Research in Organizational Behavior, 27, 223-267. https://doi.org/10.1016/S0191-3085(06)27006-0

Cohen, A. (1993). Age and Tenure in Relation to Organizational Commitment: A Meta-Analysis. Basic and Applied Social Psychology, 14(2), 143-159. https://doi.org/10.1207/s15324834basp1402_2

Cohen, A. (2000). The relationship between commitment forms and work outcomes: A comparison of three models. Human Relations, 53, 387-417. https://doi.org/10.1177/0018726700533005

Cohen, A. (2003). Multiple commitments in the workplace: An integrative approach. Mahwah, NJ: Lawrence Erlbaum Associates. https://doi.org/10.4324/9781410607423

Cohen, A., \& Freund, A. (2005). A longitudinal analysis of the relationship between multiple commitments and withdrawal cognitions. Scandinavian Journal of Management, 21(3), 329-351. https://doi.org/10.1016/j.scaman.2004.06.004

Cohen, A., \& Lowenberg, G. (1990). A reexamination of the side-bet theory as applied to organizational commitment: A meta-analysis. Human Relations, 43(10), 1015-1050. https://doi.org/10.1177/001872679004301005

Cohen, A., \& Veled-Hecht, A. (2010). The relationship between organizational socialization and commitment in the workplace among employees in long-term nursing care facilities. Personnel Review, 39(5), 537-556. https://doi.org/10.1108/00483481011064136

Cohen, B., \& Schmida, M. (1997). Informal education in Israel and North America. Journal of Jewish Education, 63(1-2), 50-58. https://doi.org/10.1080/0021624970630107

Coyle-Shapiro, J. A. M. (2002). A psychological contract perspective on organizational citizenship behavior. Journal of Organizational Behavior, 23(8), 927-946. https://doi.org/10.1002/job.173

Coyle-Shapiro, J. A. M., \& Kessler, I. (2003). The employment relationship in the UK public sector: A psychological contract perspective. Journal of Public Administration Research and Theory, 13(2), 213-230. https://doi.org/10.1093/jpart/mug018

Coyle-Shapiro, J. A. M., Pereira Costa, S., Doden, W., \& Chang, C. (2019). Psychological contracts: Past, present, and future. Annual Review of Organizational Psychology and Organizational Behavior, 6, 145-169. https://doi.org/10.1146/annurev-orgpsych-012218-015212

Foote, D. A., \& Tang, T. L. P. (2008). Job satisfaction and organizational citizenship behavior (OCB). Management Decision, 46(6), 933-947. https://doi.org/10.1108/00251740810882680

Freund, A. (2005). Commitment and job satisfaction as predictors of turnover intentions among welfare workers. Administration in Social Work, 29(2), 5-21. https://doi.org/10.1300/J147v29n02_02 
Fuller, J. B., Patterson, C. E. P., Hester, K., \& Stringer, D. Y. (1996). A quantitative review of research on charismatic leadership. Psychological Reports, 78, 271-287. https://doi.org/10.2466/pr0.1996.78.1.271

Galin, A., \& Avraham, S. (2009). A cross-cultural perspective on aggressiveness in the workplace: A comparison between Jews and Arabs in Israel. Cross-Cultural Research, 43(1), 30-45. https://doi.org/10.1177/1069397108326273

Gerstner, C. R., \& Day, D. V. (1997). Meta-Analytic review of leader-member exchange theory: Correlates and construct issues. Journal of Applied Psychology, 82(6), 827-844. https://doi.org/10.1037/0021-9010.82.6.827

Greenberg, J. (1990). Organizational justice: Yesterday, today, and tomorrow. Journal of Management, 16, 399-432. https://doi.org/10.1177/014920639001600208

Hackett, R. D., \& Lapierre, L. M. (2004, August). A meta-analytical explanation of the relationship between LMX and OCB. In Academy of Management Proceedings (Vol. 2004, No. 1, pp. T1-T6). Briarcliff Manor, NY 10510: Academy of Management. https://doi.org/10.5465/ambpp.2004.13862454

Hammond, M. M., Neff, N. L., Farr, J. L., Schwall, A. R., \& Zhao, X. (2011). Predictors of individual-level innovation at work: A meta-analysis. Psychology of Aesthetics, Creativity, and the Arts, 5(1), 90-105. https://doi.org/10.1037/a0018556

Hasenfeld, Y., \& Schmid, H. (1989). The community center as a human service organization. Nonprofit and Voluntary Sector Quarterly, 18(1), 47-61. https://doi.org/10.1177/089976408901800105

Henderson, A. A., Foster, G. C., Matthews, R. A., \& Zickar, M. J. (2020). A psychometric assessment of OCB: Clarifying the distinction between OCB and CWB and developing a revised OCB measure. Journal of Business and Psychology, 35(6), 697-712. https://doi.org/10.1007/s10869-019-09653-8

Hoppe, A., Fujishiro, K., \& Heaney, C. A. (2014). Workplace racial/ethnic similarity, job satisfaction, and lumbar back health among warehouse workers: Asymmetric reactions across racial/ethnic groups. Journal of Organizational Behavior, 35(2), 172-193. https://doi.org/10.1002/job.1860

Israeli Association of Community Centers. (2020, March 22). Retrieved from https://www.matnasim.org.il/?CategoryID $=2397$

Judge, T. A., \& Piccolo, R. F. (2004). Transformational and transactional leadership: A meta-analysis test of their relative validity. Journal of Applied Psychology, 89, 755-768. https://doi.org/10.1037/0021-9010.89.5.755

Karsten, M. F. (1994). Management and Gender: Issues and Attitudes. Westport, CT: Quorum Books.

Khaola, P., \& Rambe, P. (2020). The effects of transformational leadership on organisational citizenship behaviour: The role of organisational justice and affective commitment. Management Research Review, 44(3), 381-398. https://doi.org/10.1108/MRR-07-2019-0323

Kidder, D. L., \& Parks, J. M. (2001). The good soldier: Who is s(he)? Journal of Organizational Behavior, 22(8), 939-959. https://doi.org/10.1002/job.119

Klein, H. J., Cooper, J. T., Molloy, J. C., \& Swanson, J. A. (2014). The assessment of commitment: Advantages of a unidimensional, target-free approach. Journal of Applied Psychology, 99, 222-238. https://doi.org/10.1037/a0034751

Klein, H. J., Solinger, O. N., \& Duflot, V. (2022). Commitment system theory: The evolving structure of commitments to multiple targets. Academy of management review, 47(1), 116-138. https://doi.org/10.5465/amr.2018.0031

LePine, J. A., Erez, A., \& Johnson, D. E. (2002). The nature and dimensionality of organizational citizenship behavior: A critical review and meta-analysis. Journal of Applied Psychology, 87, 52-75. https://doi.org/10.1037/0021-9010.87.1.52

Liden, R. C., \& Maslyn, J. M. (1998). Multidimensionality of leader-member exchange: An empirical assessment through scale development. Journal of management, 24(1), 43-72. https://doi.org/10.1016/S0149-2063(99)80053-1

Liden, R. C., Sparrowe, R. T., \& Wayne, S. J. (1997). Leader-member exchange theory: The past and potential for the future. Research in Personnel and Human Resources Management, 15, 47-120. 
Liden, R. C., Wayne, S. J., \& Stilwell, D. (1993). A longitudinal study on the early development of leader-member exchanges. Journal of Applied Psychology, 78(4), 662-674. https://doi.org/10.1037/0021-9010.78.4.662

Lowe, K. B., Kroeck, K. G., \& Sivasubramaniam, N. (1996). Effectiveness correlates of transformational leadership and transactional leadership: A two-sample study. Journal of Management, 25, 897-933.

Marstand, A. F., Martin, R., \& Epitropaki, O. (2017). Complementary person-supervisor fit: An investigation of supplies-values (SV) fit, leader-member exchange (LMX) and work outcomes. The Leadership Quarterly, 28(3), 418-437. https://doi.org/10.1016/j.leaqua.2016.10.008

Martin, C. L., \& Bennett, N. (1996). The role of justice judgments in explaining the relationship between job satisfaction and organizational commitment. Group \& Organization Management, 21(1), 84-104. https://doi.org/10.1177/1059601196211005

Mathieu, J. E., \& Farr, J. L. (1991). Further Evidence of the Discriminant Validity of Measures of Organizational Commitment, Job Involvement, and Job Satisfaction. Journal of Applied Psychology, 76, 127-133. https://doi.org/10.1037/0021-9010.76.1.127

Miao, C., Qian, S., Banks, G. C., \& Seers, A. (2020). Supervisor-subordinate guanxi: A meta-analytic review and future research agenda. Human Resource Management Review, 30(2), 100702. https://doi.org/10.1016/j.hrmr.2019.100702

Mohammad, J., Quoquab Habib, F., \& Zakaria, S. (2010). Organizational citizenship behavior and commitment: do age and tenure make any difference? Business Management Quarterly Review, 1(3), 28-49.

Moorman, R. H. (1991). Relationship between organizational justice and organizational citizenship behaviors: Do fairness perceptions influence employee citizenship? Journal of Applied Psychology, 76(6), 845-855. https://doi.org/10.1037/0021-9010.76.6.845

Morrow, P. C. (1983). Concept redundancy in organizational research: The case of work commitment. Academy of Management Review, 8, 486-500. https://doi.org/10.5465/amr.1983.4284606

Morrow, P. C. (1993). The theory and measurement of work commitment. Greenwich, CT: Jai Press Inc.

Niehoff, P. B., \& Moorman, H. R. (1993). Justice as a mediator of the relationship between methods of monitoring and organizational citizenship behavior. Academy of Management Journal, 36, 527-556. https://doi.org/10.5465/256591

Ocampo, L., Acedillo, V., Bacunador, A. M., Balo, C. C., Lagdameo, Y. J., \& Tupa, N. S. (2018). The historical review of development of organizational citizenship behavior and its implication on twenty-first century. Personal Review, 47(4), 821-862. https://doi.org/10.1108/PR-04-2017-0136

Organ, D. W., \& Konovsky, M. (1989). Cognitive versus affective determinants of organizational citizenship behavior. Journal of applied psychology, 74(1), 157-164. https://doi.org/10.1037/0021-9010.74.1.157

Organ, D. W., Podsakoff, P. M., \& MacKenzie S. P. (2006). Organizational Citizenship Behavior: Its Nature, Antecedents, and Consequences. London: Sage Publications. https://doi.org/10.1111/j.1744-6570.2006.00043_9.x

Organ, D. W. (1988). Organizational Citizenship Behavior: The good soldier syndrome. Lexington, MA: Lexington Books.

Organ, D. W. (1990). The motivational basis of organizational citizenship behavior. Research in Organizational Behavior, 12, 43-72.

Perlman, R. (1981). Community Work in the Israeli Community Centers-Report and Recommendations. The Israeli Association of Community Centers, Jerusalem, Israel.

Podsakoff, P. M., Mackenzie, S. B, Paine, J. B., \& Bacharach, G. D. (2000). Organizational citizenship behaviors: A critical review of the theoretical and empirical literature and suggestions for future research. Journal of Management, 26, 513-563. https://doi.org/10.1177/014920630002600307

Quratulain, S., Khan, A. K., Crawshaw, J. R., Arain, G. A., \& Hameed, I. (2018). A study of employee affective organizational commitment and retention in Pakistan: The roles of psychological contract breach and norms of reciprocity. The International Journal of Human Resource Management, 29(17), 2552-2579. https://doi.org/10.1080/09585192.2016.1254099 
Ramamoorthy, N., Flood, P. C., Slattery, T., \& Sardessai, R. (2005). Determinants of innovative work behaviour: Development and test of an integrated model. Creativity and Innovation Management, 14(2), 142-150. https://doi.org/10.1111/j.1467-8691.2005.00334.x

Randall, D. M., \& Cote, J. A. (1991). Interrelationships of work commitment constructs. Work and Occupation, 18, 194-211. https://doi.org/10.1177/0730888491018002004

Reichers, A. E. (1985). A review and re conceptualization of organizational commitment. Academy of Management Review, 10, 465-476. https://doi.org/10.5465/amr.1985.4278960

Reichers, A. E. (1986). Conflict and organizational commitment. Journal of Applied Psychology, 71, 508-514. https://doi.org/10.1037/0021-9010.71.3.508

Robinson, S. L., \& Morrison, E. W. (2000). The development of psychological contract breach and violation: A longitudinal study. Journal of Organizational Behavior, 21(5), 525-546. https://doi.org/10.1002/1099-1379(200008)21:5<525::AID-JOB40>3.0.CO;2-T

Ross, C. E. (1987). The division of labor at home. Social Forces, 65, 816-833. https://doi.org/10.2307/2578530

Rotondi, T. (1975). Organizational identification: Issues and implications. Organizational Behavior and Human Performance, 13, 95-109. https://doi.org/10.1016/0030-5073(75)90007-0

Russell, J. E., \& Rush, M. C. (1987). The effects of sex and marital/parental status on performance evaluations and attributions. Sex Roles, 17, 221-236. https://doi.org/10.1007/BF00287627

Saridakis, G., Lai, Y., Muñoz Torres, R. I., \& Gourlay, S. (2020). Exploring the relationship between job satisfaction and organizational commitment: an instrumental variable approach. The International Journal of Human Resource Management, 31(13), 1739-1769. https://doi.org/10.1080/09585192.2017.1423100

Schnake, M. (1991). Organizational citizenship: A review, proposed model, and research agenda. Human Relations, 44(7), 735-759. https://doi.org/10.1177/001872679104400706

Sears, G. J., \& Hackett, R. D. (2011). The influence of role definition and affect in LMX: A process perspective on the personality-LMX relationship. Journal of Occupational and Organizational Psychology, 84(3), 544-564. https://doi.org/10.1348/096317910X492081

Sesen, H., \& Basim, N. H. (2012). Impact of satisfaction and commitment on teachers' organizational citizenship. Educational Psychology, 32(4), 475-491. https://doi.org/10.1037/0021-9010.68.4.653

Smith, C. A., Organ, D. W., \& Near, J. P. (1983). Organizational citizenship behavior: its nature and antecedents. Journal of Applied Psychology, 68, 653-663. https://doi.org/10.1037/0021-9010.68.4.653

Stetsky, S., \& Kamagina, V. (2021). A new look on Community Centers under modern trends in urban design and development. In E3S Web of Conferences (Vol. 244, p. 06005). EDP Sciences. https://doi.org/10.1051/e3sconf/202124406005

Timalsina, R., KC, S., Rai, N., \& Chhantyal, A. (2018). Predictors of organizational commitment among university nursing Faculty of Kathmandu Valley, Nepal. BMC nursing, 17(1), 1-8. https://doi.org/10.1186/s12912-018-0298-7

Torlak, N. G., Kuzey, C., Sait Dinç, M., \& Budur, T. (2021). Links connecting nurses' planned behavior, burnout, job satisfaction, and organizational citizenship behavior. Journal of Workplace Behavioral Health, 36(1), 77-103. https://doi.org/10.1080/15555240.2020.1862675

van Rossenberg, Y. G. T., Klein, H. J., Asplund, K., Bentein, K., Breitsohl, H., Cohen, A., ... \& Yalabik, Z. Y. (2018). The future of workplace commitment: key questions and directions. European Journal of Work and Organizational Psychology, 27(2), 153-167. https://doi.org/10.1080/1359432X.2018.1443914

Vandenberg, R. J., \& Lance, C. E. (1992). Examining the causal order of job satisfaction and organizational commitment. Journal of management, 18(1), 153-167. https://doi.org/10.1177/014920639201800110

Yukl, G. (1989). Managerial leadership: A review of theory and research. Journal of Management, 15, 251-289. https://doi.org/10.1177/014920638901500207

Yun, S., Takeuchi, R., \& Liu, W. (2007). Employee self-enhancement motives and job performance behaviors: Investigating the moderating effects of employee role ambiguity and managerial perceptions of employee commitment. Journal of Applied Psychology, 92(3), 745-756. https://doi.org/10.1037/0021-9010.92.3.745 
Zhao, H. A. O., Wayne, S. J., Glibkowski, B. C., \& Bravo, J. (2007). The impact of psychological contract breach on work-related outcomes: a meta-analysis. Personnel Psychology, 60(3), 647-680. https://doi.org/10.1111/j.1744-6570.2007.00087.x

Zhong, M., Wayne, S. J., \& Michel, E. J. (2021). When the Past and the Present Collide: Contrast Effect of Sequential Psychological Contract Breaches on Employee Outcomes. Journal of Management, 01492063211061255. https://doi.org/10.1177/01492063211061255

\section{Copyrights}

Copyright for this article is retained by the author(s), with first publication rights granted to the journal.

This is an open-access article distributed under the terms and conditions of the Creative Commons Attribution license (http://creativecommons.org/licenses/by/4.0/). 